\title{
Is it time to incorporate surgery in the treatment of stage IV non-small cell lung cancer?
}

Citation for published version (APA):

Hendriks, L. E. L., \& Dingemans, A-M. C. (2019). Is it time to incorporate surgery in the treatment of stage IV non-small cell lung cancer? Lung Cancer, 129, 95-97. https://doi.org/10.1016/j.lungcan.2019.01.011

Document status and date:

Published: 01/03/2019

DOI:

10.1016/j.lungcan.2019.01.011

Document Version:

Publisher's PDF, also known as Version of record

Document license:

Taverne

\section{Please check the document version of this publication:}

- A submitted manuscript is the version of the article upon submission and before peer-review. There can be important differences between the submitted version and the official published version of record.

People interested in the research are advised to contact the author for the final version of the publication, or visit the DOI to the publisher's website.

- The final author version and the galley proof are versions of the publication after peer review.

- The final published version features the final layout of the paper including the volume, issue and page numbers.

Link to publication

\footnotetext{
General rights rights.

- You may freely distribute the URL identifying the publication in the public portal. please follow below link for the End User Agreement:

www.umlib.nl/taverne-license

Take down policy

If you believe that this document breaches copyright please contact us at:

repository@maastrichtuniversity.nl

providing details and we will investigate your claim.
}

Copyright and moral rights for the publications made accessible in the public portal are retained by the authors and/or other copyright owners and it is a condition of accessing publications that users recognise and abide by the legal requirements associated with these

- Users may download and print one copy of any publication from the public portal for the purpose of private study or research.

- You may not further distribute the material or use it for any profit-making activity or commercial gain

If the publication is distributed under the terms of Article $25 \mathrm{fa}$ of the Dutch Copyright Act, indicated by the "Taverne" license above, 
Editorial

\section{Is it time to incorporate surgery in the treatment of stage IV non-small cell lung cancer?}

Oligometastatic disease is an intermediate state between localized disease and more widespread metastases [1]. Oligometastatic non-small cell lung cancer (NSCLC) is usually defined as a maximum of three (European Society for Medical Oncology (ESMO)) or five (National Comprehensive Cancer Network (NCCN)) metastases [2,3]. There is a biological rationale to administer local ablative therapy (LAT, with or without LAT of the metastases), as metastases can arise from both the primary tumor as well as the metastases; LAT can prevent reseeding from the treated sites $[4,5]$. LAT of (synchronous) oligometastases, usually preceded or followed by systemic anticancer therapy, is mentioned in the ESMO and NCCN guidelines [2,3]. LAT has gained interest with the increasing availability of minimally invasive surgery and stereotactic radiotherapy (SRT) combined with the promising survival described in retrospective series and single arm/randomized phase II trials [6-9]. Recently, a significant improvement in overall survival (OS) was reported in a randomized phase II trial when LAT (surgery and/or SRT) was added to maintenance treatment/observation in synchronous oligometastatic NSCLC patients responding to induction systemic treatment. Median OS was 41.2 (LAT) versus 17 months (control) with a hazard ratio (HR) of 0.40 , $(p=0.017)$ [8]. Despite that in this phase II trial three metastatic sites were allowed, $68 \%$ had only a single metastasis, and $48 \%$ had N0-1 disease [10]. On a populationbased level, it is unknown what the benefit is of LAT of the primary tumor. Therefore, the study of Sun et al. [11] published in this issue of Lung Cancer, is of interest.

The authors used the US National Cancer Institute Surveillance, Epidemiology and End Results database to select all pathologically proven stage IV M1b (TNM7) NSCLC patients $(\mathrm{N}=39,655)$ diagnosed between 2010 and 2015. Those with T0, M1a or M1 not otherwise specified (without proven extrathoracic metastasis) were excluded. Primary outcome was OS, secondary outcome was lung cancer specific mortality (LCSM). Survival of patients with a primary tumor resection ( $N=1,206$ (3\%), with $83.8 \%$ (bi)lobectomy), was compared with those without primary tumor resection ( $\mathrm{N}=38,449$, the non-surgical group). Survival of a propensity score matched (PSM) surgical and non-surgical group (both $\mathrm{N}=315$ ) was also compared. In the non-matched groups, surgical patients had a more favourable clinical profile, with among others significantly younger age, a lower $\mathrm{T}$ - and N-status, better differentiated tumors, more often single-organ metastases and more often also a metastasectomy compared to the non-surgical patients. In the non-matched group, median OS was superior in the surgical group (14 versus 6 months, HR 0.49 (95\% CI 0.46-0.52), p < 0.001). In the PSM cohort, median OS remained superior (11 versus 7 months, HR 0.65 (95\% CI 0.55-0.78), $\mathrm{p}<0.001)$. Patients $(\mathrm{N}=644)$ referred for surgery of the primary tumor, but not receiving surgery (without dying before surgery), had a significantly worse median OS compared with those that received surgery ( 6 versus 14 months, HR 0.46 (95\% CI 0.41 $0.51), \mathrm{p}<0.001)$. In multivariate analysis, primary tumor resection was independently associated with improved OS (HR 0.60; 95\% CI $0.56-0.64, \mathrm{p}<0.001$ ) in the whole cohort and in the surgery recommended cohort (HR 0.62; 95\% CI 0.55-0.70, p < 0.001). For LCSM, similar survival differences were found.

This is the first population-based analysis evaluating the benefit of surgery for the primary tumor in stage IV M1b (TNM7) NSCLC. Even in the metastatic setting, surgery improved the outcome of these patients with lobectomy showing the most survival gain. What were the reasons to offer surgery to these metastatic patients, and how where they selected? And does this mean we should offer primary tumor surgery to stage IV M1b patients, especially those with other good prognostic factors such as low TN-status and single-organ metastases?

Patient characteristics were similar to a Dutch population based study $(\mathrm{N}=11,094)$, evaluating survival in stage IV NSCLC in relation to number of organs with metastases and TN-stage [12]. Percentage of single organ metastases (59\% vs $51 \%$ ) and percentage of N0-1 disease (29.8\% versus $31.6 \%$ ) was comparable. Patients with single-organ metastases, especially those with low TN-status (T1-2 and N0-1) had a superior OS compared to those with metastases in two or more organs or with high TN-status (T3-4, and/or N2-3). However, the median OS of single-organ metastases patients with low TN-status was with 8.5 months lower than the median OS of the patients with a resected primary tumor in the current analysis (14 months) [12]. Interestingly, in the Dutch study, patients with a documented ${ }^{18}$ Fluodeoxyglucose positron emission tomography $\left({ }^{18} \mathrm{FDG}\right.$-PET) had a superior survival compared to those without (median 11.6 versus 8.2 months) [12], which can be explained by the upstaging effects of ${ }^{18}$ FDG-PET (Will Rogers phenomenon) [13]. In the present study, data on ${ }^{18}$ FDG-PET was not available, although adequate imaging for stage IV patients eligible for LAT is advised in the ESMO as well as the NCCN guidelines and in a recent European Organisation for Research and Treatment of Cancer (EORTC) statement $[2,3,14]$. It is possible that part of the survival differences attributed to primary tumor surgery was caused by imbalances in extent of staging. Furthermore, the current study only evaluated number of organs with metastases, but did not specify number of metastases per organ. It is known from the TNM8 data that number of extrathoracic metastases, even within a single organ, is associated with survival [15].

Other questions that need to be answered before incorporating primary tumor surgery into daily practice for stage IV NSCLC is how to select patients, and whether LAT needs to be surgery. Adequate staging is necessary, and selection of oligometastatic good performance status patients with low TN-status, eligible for LAT seems best. In the current 
study, information on performance status is lacking and it is not clear whether especially synchronous oligometastatic NSCLC patients or oligoprogressive patients were treated with surgery of the primary, making, despite the PSM, comparison of groups difficult. Furthermore, definition of oligometastatic NSCLC varies $[2,3,6,10]$. A uniform definition is needed to design and compare clinical trials. The EORTC Lung Cancer Group has recently proposed a consensus definition for synchronous oligometastatic NSCLC [16]. Additionally, as only a small percentage of oligometastatic patients obtains long-term survival with LAT, better selection methods are needed. In the current study, 5-year survival of patients with primary tumor surgery was $20 \%$. It is possible that integrated molecular subtyping can improve selection for LAT, as in colorectal cancer this subtyping combined with a clinical risk stratification was able to stratify patients into low, intermediate and high risk groups, with clearly different survival [17].

Although not specifically addressed in the current study, a combination of local disease LAT plus LAT of all metastases is likely to provide more survival benefit than primary tumor LAT only. Indeed, both ESMO and NCCN guidelines advise LAT of all visible disease in oligometastatic patients [2,3]. It is unknown whether the patients in the current study were also treated with LAT to other metastatic sites, as $26.9 \%$ underwent metastasectomy of at least one metastasis, but information on radiotherapy was not provided. It is possible that response to induction systemic therapy is able to select patients with a better prognosis that will probably have the most benefit of LAT. Cross-trial comparison is difficult, but in the Gomez et al. trial, only patients responding to induction systemic treatment were treated with LAT: median OS was 41.2 months [8]. In the single arm phase II trial of De Ruysscher et al. almost all patients received systemic therapy but $54 \%$ was treated with concurrent chemoradiotherapy: median OS was 13.5 months with a five-year survival of 7.7\% [7]. The proportion of patients receiving (induction) systemic treatment in the article of Sun et al. is unknown. Asian race was associated with improved survival in this study. These patients often have a targetable driver mutation [18] and they have a superior survival compared to non-driver mutated patients [19]. It is also possible that these patients received surgery because of oligoprogression, as LAT is an accepted treatment method in oligoprogressive driver mutated patients.

The reported phase II trials included only patients eligible for LAT to the primary as well as the metastatic sites $[6-8,10]$. With the exception of the Iyengar et al trial [6], choice of LAT was free. In the current analysis, the authors did not evaluate whether SRT yielded results comparable to surgery. In a recent systematic review and meta-analysis, radiotherapy to the primary also improved survival in oligometastatic (synchronous/metachronous) NSCLC [20]. Furthermore, immune checkpoint inhibitors (ICI) have revolutionized the treatment strategies for NSCLC. Radiotherapy and ICI act synergistically, while this is not the case for surgery [21]. Therefore, it is possible that in the ICI era radiotherapy is thought to be the preferred LAT technique.

In conclusion, the current study adds evidence to the statement that LAT improves survival in a (selected, probably oligometastatic/oligoprogressive) group of stage IV NSCLC patients. Accurate staging is essential, and research should focus on how to select patients that benefit most from LAT (e.g. the role of N2-N3 disease: this is evaluated in the SARON trial (NCT 02417662)), the optimal type of LAT, and the role of ICI (evaluated in for example NCT NCT02316002). To compare these trials, a single oligometastatic definition is needed.

\section{Funding}

None.

\section{Conflicts of interest}

LH: none related to the current manuscript. outside of current manuscript: research funding Roche, Boehringer Ingelheim (both institution), advisory board: Boehringer, BMS, (both institution, BMS also self), travel reimbursement: Roche, BMS (self); mentorship program with key opinion leaders: funded by AstraZeneca; fees for educational webinars: Quadia (self).

A-MD: none related to current manuscript, outside of current manuscript: advisory board BMS, MSD, Roche, Eli Lilly, Takeda, Pfizer, Boehringer Ingelheim (all institution). Research grant: BMS (institution).

\section{Acknowledgement}

None.

\section{References}

[1] S. Hellman, R.R. Weichselbaum, Oligometastases, J. Clin. Oncol. 13 (1) (1995) 8-10.

[2] NCCN Guidelines Non-small Cell Lung Cancer. Version 2.2019, (2019) Available from: https://www.nccn.org/professionals/physician gls/pdf/nscl.pdf.

[3] D. Planchard, S. Popat, K. Kerr, S. Novello, E.F. Smit, C. Faivre-Finn, et al, Metastatic non-small cell lung cancer: ESMO Clinical Practice Guidelines for diagnosis, treatment and follow-up, Ann. Oncol. 29 (Suppl._4) (2018) iv192-iv237.

[4] G. Macintyre, P. Van Loo, N.M. Corcoran, D.C. Wedge, F. Markowetz, C.M. Hovens, How subclonal modeling is changing the metastatic paradigm, Clin. Cancer Res. 23 (3) (2017) 630-635.

[5] P.K. Newton, J. Mason, K. Bethel, L. Bazhenova, J. Nieva, L. Norton, et al, Spreaders and sponges define metastasis in lung cancer: a Markov chain Monte Carlo mathematical model, Cancer Res. 73 (9) (2013) 2760-2769.

[6] P. Iyengar, Z. Wardak, D.E. Gerber, V. Tumati, C. Ahn, R.S. Hughes, et al., Consolidative radiotherapy for limited metastatic non-small-cell lung cancer: a phase 2 randomized clinical trial, JAMA Oncol. 4 (1) (2018) e173501.

[7] D. De Ruysscher, R. Wanders, L.E. Hendriks, A. van Baardwijk, B. Reymen, R. Houben, et al., Progression-Free-Survival and Overall Survival beyond 5 years of non-small cell lung cancer patients with synchronous oligometastases treated in a prospective phase II trial (NCT 01282450), J. Thorac. Oncol. 13 (12) (2018) 1958-1961.

[8] D. Gomez, C. Tang, J. Zhang, G.R. Blumenschein Jr., M. Hernandez, J. Lee, et al., Local Consolidative Therapy (LCT) improves Overall Survival (OS) Compared to Maintenance Therapy/Observation in Oligometastatic Non-Small Cell Lung Cancer (NSCLC): final results of a multicenter, randomized, controlled phase 2 trial, ASTRO 2018 (2018) abstract LBA3.

[9] A.B. Ashworth, S. Senan, D.A. Palma, M. Riquet, Y.C. Ahn, U. Ricardi, et al., An individual patient data metaanalysis of outcomes and prognostic factors after treatment of oligometastatic non-small-cell lung cancer, Clin. Lung Cancer 15 (5) (2014) 346-355.

[10] D.R. Gomez, G.R. Blumenschein Jr., J.J. Lee, M. Hernandez, R. Ye, D.R. Camidge, et al., Local consolidative therapy versus maintenance therapy or observation for patients with oligometastatic non-small-cell lung cancer without progression after first-line systemic therapy: a multicentre, randomised, controlled, phase 2 study, Lancet Oncol. 17 (12) (2016) 1672-1682.

[11] Z. Sun, X. Sui, F. Yang, J. Wang, Effects of primary tumor resection on the survival of patients with stage IV extrathoracic metastatic non-small cell lung cancer: a population-based study, Lung Cancer (18) (2018) S0169-5002, https://doi.org/10 1016/j.lungcan 2018.11.012 30639-1.

[12] L.E. Hendriks, J.L. Derks, P.E. Postmus, R.A. Damhuis, R.M. Houben, E.G. Troost, et al., Single organ metastatic disease and local disease status, prognostic factors for overall survival in stage IV non-small cell lung cancer: results from a populationbased study, Eur. J. Cancer 51 (17) (2015) 2534-2544.

[13] K.G. Chee, D.V. Nguyen, M. Brown, D.R. Gandara, T. Wun, P.N. Lara Jr., Positron emission tomography and improved survival in patients with lung cancer: the Will Rogers phenomenon revisited, Arch. Intern. Med. 168 (14) (2008) 1541-1549.

[14] N.M. deSouza, Y. Liu, A. Chiti, D. Oprea-Lager, G. Gebhart, B.E. Van Beers, et al., Strategies and technical challenges for imaging oligometastatic disease: recommendations from the European Organisation for Research and Treatment of Cancer imaging group, Eur. J. Cancer 91 (2018) 153-163.

[15] W. Eberhardt, A. Mitchell, J. Crowley, H. Kondo, Y. Kim, A. Turrisi, et al., The IASLC lung Cancer Staging project: proposals for the revision of the M descriptors in the forthcoming eighth edition of the TNM classification of lung cancer, J. Thorac. Oncol. 10 (2015) 1515-1522.

[16] A. Dingemans, L. Hendriks, T. Berghmans, A. Levy, B. Hasan, C. Faivre-Finn, et al., MA25.02 - Searching for a Definition of Synchronous Oligometastatic (sOMD)NSCLC: a Consensus From Thoracic Oncology Experts WCLC, (2018) sept-26-2018; Toronto2018. p. abstract MA 25.02.

[17] S.P. Pitroda, N.N. Khodarev, L. Huang, A. Uppal, S.C. Wightman, S. Ganai, et al., Integrated molecular subtyping defines a curable oligometastatic state in colorectal liver metastasis, Nat. Commun. 9 (1) (2018) 1793.

[18] Y. Shi, J.S. Au, S. Thongprasert, S. Srinivasan, C.M. Tsai, M.T. Khoa, et al., A prospective, molecular epidemiology study of EGFR mutations in Asian patients with advanced non-small-cell lung cancer of adenocarcinoma histology (PIONEER), J. Thorac. Oncol. 9 (2) (2014) 154-162. 
[19] T.S. Mok, Y.L. Wu, S. Thongprasert, C.H. Yang, D.T. Chu, N. Saijo, et al., Gefitinib or carboplatin-paclitaxel in pulmonary adenocarcinoma, N. Engl. J. Med. 361 (10) (2009) 947-957.

[20] F. Petrelli, A. Ghidini, M. Cabiddu, G. Tomasello, A. De Stefani, L. Bruschieri, et al., Addition of radiotherapy to the primary tumour in oligometastatic NSCLC: A systematic review and meta-analysis, Lung Cancer 126 (2018) 194-200.

[21] T. Kordbacheh, J. Honeychurch, F. Blackhall, C. Faivre-Finn, T. Illidge, Radiotherapy and anti-PD-1/PD-L1 combinations in lung cancer: building better translational research platforms, Ann. Oncol. 29 (2) (2018) 301-310.
Lizza E.L. Hendriks, Anne-Marie C. Dingemans* Dept. of Pulmonary Diseases, GROW - School for Oncology and Developmental Biology, Maastricht University Medical Center +, PO Box 5800, 6202 AZ, Maastricht, the Netherlands

E-mail addresses: Lizza.hendriks@mumc.nl (L.E.L. Hendriks), a.dingemans@mumc.nl (A.-M.C. Dingemans).

* Corresponding author. 